\title{
PEMODELAN STATISTIK COVID19 DI INDONESIA ANALISA PERBANDINGAN MODEL
}

(STATISTICS MODEL OF COVID19 IN INDONESIA : COMPARATIVE MODEL ANALYSE)

\author{
Novandhita Adi Satria', Agustina Elisa Dyah Purwandari² \\ Badan Pusat Statistik Kotawaringin Barat ${ }^{1}$ \\ Badan Pusat Statistik Kotawaringin Barat ${ }^{2}$ \\ Jalan P Diponegoro No 01, Arut Selatan, Kotawaringin Barat, Kalimantan Tengah \\ E-mail: novandhita.satria@bps.go.id
}

\begin{abstract}
ABSTRAK
Novel coronavirus yang muncul di China dan sudah menyebar pada ratusan negara akan menjadi pandemi penyakit menular terburuk di abad ini, jika dilihat dari jumlah yang terinfeksi dan kematian yang diakibatkan. Dampak sosial dan ekonomi yang ditimbulkan akibat pandemi COVID-19 juga sangatlah besar, sehingga permodelan statistik terkait COVID19 sangat dibutuhkan pemerintah dalam menentukan arah kebijakan. Peramalan kapan saja puncak pandemi sangat dibutuhkan terutama di bidang kesehatan karena pada periode puncak-puncak tersebut, beban akan berat. Berdasarkan analisis data penambahan harian kasus positif COVID-19 Indonesia dengan smoothing data menggunakan moving average mingguan dan dua mingguan, penambahan harian kasus positif COVID-19 saat ini sudah memasuki gelombang penyebaran kelima yang mana terjadi mulai minggu ketiga bulan Juli 2020 dan belum mencapai puncaknya. Sementara itu, analisis data penambahan harian kasus positif COVID-19 dari awal muncul sampai dengan sekarang ini cenderung mengikuti persamaan polinomial kubik dengan model terbaik yang dihasilkan bisa menjelaskan 92,76 persen pergerakan data (dengan tingkat kepercayaan 95 persen). Hasil permodelan yang diperoleh meramalkan penyebaran COVID-19 akan berpuncak pada minggu ketiga November hingga minggu pertama Desember 2020. Sementara itu, pandemi akan berakhir pada minggu kedua bulan April 2021. Hal ini terjadi apabila kondisi penyebaran COVID-19 di masyarakat masih mengikuti pola yang terjadi saat ini.
\end{abstract}

Kata kunci: Covid19, Moving Average

\section{ABSTRACT}

The new corona virus that has emerged in China and spread to hundreds of countries will be the worst infectious disease pandemic in this century, when viewed from the number infected and the deaths it causes. The social and economic impacts of the COVID-19 pandemic are also very large, so statistical modeling related to COVID19 is needed by the government in determining policy direction. Forecasting at any time of the peak of the pandemic is needed, especially in the health sector, because at the peak the burden will be heavier. Based on the analysis of additional data on positive daily cases of COVID-19 in Indonesia with data smoothing using weekly and biweekly moving averages, the addition of daily positive COVID-19 cases has now entered the fifth wave of change that occurred starting the third week of July 2020 and has not yet reached its peak. Meanwhile, data analysis on the addition of positive daily cases of COVID19 from the start to date tends to follow the cubic polynomial equation with the best result model explaining 92.76 percent of data movements (with confident 95 persen). The modeling results obtained predict that the spread of COVID-19 will reach its peak in the third week of November to the first week of December 2020. Meanwhile, the pandemic will end in the second week of April 2021. This happens if conditions are spread. The transmission of COVID-19 in the community still follows the existing pattern. currently.

Keywords: Covid19, Moving Average 


\section{PENDAHULUAN}

Novel coronavirus yang muncul di China dan sudah menyebar pada ratusan negara nampaknya akan menjadi pandemi penyakit menular terburuk di abad ini, jika dilihat dari jumlah yang terinfeksi dan kematian yang diakibatkan. Covid19 merupakan penyakit dengan penyebabnya infeksi Severe Acute Respiratory Syndrome Coronavirus 2 (SARS-CoV-2). Indonesia yang merupakan negara keempat terpadat di dunia diprediksi membutuhkan waktu yang lebih lama untuk bisa keluar dari pandemi ini, jika dibandingkan dengan negara berpenduduk lebih sedikit (Nuraini, 2020).

Sejak munculnya COVID-19, banyak permodelan dan peramalan statistik yang sudah dilakukan oleh para peneliti. Dari hasil permodelan dan peramalan tersebut menunjukkan berbagai variasi hasil yang berbeda-beda. Di Indonesia sendiri sudah ada beberapa penelitian permodelan statistik terkait COVID-19. Namun terus meluasnya kasus infeksi COVID-19 ke berbagai daerah di Indonesia menyebabkan model statistik yang sudah terbentuk juga kemudian ikut berubah. Hal ini menjadi bukti sulitnya melakukan modeling yang akurat untuk meramalkan penyebaran COVID-19.

Pada dasarnya data yang lengkap terkait Covid19 sangat dibutuhkan dalam peramalan, tentunya untuk mengetahui puncak pandemi. Puncak pandemi sangat diharapkan karena akan menjadi momen titik balik dengan kasus yang mulai menurun setelahnya dan akan berakhir dengan nol. Hal yang sangat disayangkan adalah ketika kurva telah rata, tetapi belum mencapai puncaknya. Artinya, kasus masih akan terus meningkat. Saat ini puncak pandemi makin sulit diprediksi karena sangat dinamis dengan perilaku masyarakat. Jika puncak pandemi belum diketahui, maka beban bidang kesehatan masih akan terus bertambah. Selain itu, dampak sosial dan ekonomi yang ditimbulkan pandemi COVID-19 masih akan terus berlangsung. Oleh sebab itu, permodelan statistik terkait COVID19 sangat dibutuhkan pemerintah dalam menentukan arah kebijakan untuk meminimalisir dampak yang ditimbulkan.

Penelitian ini bertujuan untuk mendapatkan peramalan kapan saja puncak gelombang akan terjadi. Hal ini dilakukan dengan melakukan perbandingan model-model yang ada untuk mendapatkan model terbaiknya. Selain itu, juga akan dilakukan peramalan mengenai puncak gelombang besar (yang juga menjadi titik balik penurunan penambahan kasus positif) beserta dengan kapan pandemi akan berakhir.

Hasil peramalan tentunya bukan untuk menimbulkan ketakutan, tetapi membantu pemerintah menentukan kebijakan yang tepat dan memberikan edukasi kepada masyarakat perihal berakhirnya pandemi di Indonesia. Hasil peramalan yang menemukan kapan saja pandemi mencapai puncak pada setiap periodenya akan sangat membantu bidang kesehatan untuk menyiapkan ventilator, ruang isolasi, tenaga kesehatan, begitu pula dengan APD. Tanpa adanya peramalan, kebijakan yang diambil akan sangat tidak tepat.

Beberapa penelitian yang telah dilakukan terkait dengan fitting model Covid19 diantaranya adalah Nuraini, dkk (2020) yang mana estimasi model Covid19 Indonesia mengikuti pola negara Korea Selatan, dengan tingginya tingkat kedisplinan dalam pencegahan. Berdasarkan fiting model yang dihasilkan, ramalan epidemi akan berakhir di Indonesia pada pertengahan April 2020.

Ankarali, dkk (2020) dalam jurnalnya yang melakukan analisis perbandingan mendapatkan hasil bahwa model kubik lebih tepat digunakan dalam penelitian di Cina, Italia, Korea Selatan, dan Turki sejak awal kasus masing-masing. Perbedaan keparahan kasus terlihat mulai minggu kedua. Faktor lain seperti iklim dan Perbedaan genetik ikut andil dalam memperkuat model, selain juga berpengaruh pada penyebaran dan transmisi virus.

\section{METODE}

Data yang digunakan adalah penambahan data harian kasus terkonfirmasi positif pada level nasional (Indonesia) dari laman resmi Covid19 Indonesia pada https://covid19.go.id. Periode data harian yang digunakan mulai tanggal 2 Maret 2020 hingga 13 Agustus 2020. Pengolahan data sekunder tersebut dilakukan menggunakan program e-views dan Microsoft Excel. 
Analisis yang digunakan merupakan analisis deskriptif dan inferensia pada regresi non linear, menggunakan teknik smoothing data menggunakan moving average periode mingguan dan dua mingguan. Pada akhirnya akan dilakukan perbandingan model untuk mendapatkan model terbaik dan peramalan berdasarkan model terbaik yang didapat.

Model data dalam analisis regresi non linear (untuk data time series) pada (Garson, 2012) diantaranya

a. Model Linear

Persamaan umum mengikuti

$$
\mathrm{Y}=\mathrm{b} 0+\mathrm{b} 1 * \mathrm{t}
$$

dimana

$\mathrm{Y}=$ jumlah penambahan kasus

$\mathrm{t}=$ waktu

bo dan b1 = konstanta

b. Model Logaritma

Persamaan umum mengikuti

$$
\mathrm{Y}=\mathrm{b} 0+\mathrm{b} 1 * \ln (\mathrm{t}) \text {. }
$$

dimana

$\mathrm{Y}=$ jumlah penambahan kasus

$\mathrm{t}=$ waktu

b1 = konstanta

c. Model Kuadratik

Persamaan umum mengikuti

$$
\mathrm{Y}=\mathrm{b} 0+\mathrm{b} 1 * \mathrm{t}+\mathrm{b} 2 * \mathrm{t} \wedge 2
$$

dimana

$Y=$ jumlah penambahan kasus

$\mathrm{t}=$ waktu

b0,b1,b2 = konstanta

Jika nilai b2 positif, maka slope akan naik, dan sebaliknya

d. Model Kubik

Persamaan umum mengikuti

$$
\mathrm{Y}=\mathrm{b} 0+\mathrm{b} 1 * \mathrm{t}+\mathrm{b} 2 * \mathrm{t} \wedge 2+\mathrm{b} 3 * \mathrm{t} \wedge 3
$$

dimana

$Y=$ jumlah penambahan kasus

$\mathrm{t}=$ waktu

b0,b1,b2,b3 = konstanta

Jika nilai b3 positif, maka slope akan naik, dan sebaliknya

e. Model Eksponensial

Persamaan umum mengikuti

$$
\mathrm{Y}=\mathrm{b} 0^{*} \mathrm{e}^{\wedge}(\mathrm{b} 1 * \mathrm{t})
$$

dimana

$Y=$ jumlah penambahan kasus

$\mathrm{t}=$ waktu

b0,b1 = konstanta

Jika nilai b0 positif, maka slope akan naik, dan sebaliknya. Model ini diestimasi dengan transformasi

$$
\ln Y=\ln (\mathrm{b} 0)+\mathrm{b} 1 * \mathrm{t}
$$

f. Model Power

Persamaan umum mengikuti

$$
\mathrm{Y}=\mathrm{b} 0 *(\mathrm{t} \wedge \mathrm{b} 1)
$$

dimana

$\mathrm{Y}=$ jumlah penambahan kasus

$\mathrm{t}=$ waktu 


\section{b0,b1 = konstanta}

Jika nilai b0 positif, maka slope akan naik, dan sebaliknya. Model ini diestimasi dengan transformasi

$$
\ln Y=\ln (\mathrm{b} 0)+\mathrm{b} 1 * \ln (\mathrm{t})
$$

Pemilihan model terbaik mempertimbangkan Akaike Information Criterion (AIC), adjusted $\mathrm{R}$ square, dan uji asumsi klasik OLS, yaitu asumsi non-autokolinearitas, asumsi homoskedastisitas, dan dan asumsi normalitas. Uji asumsi non-autokolinearitas menggunakan uji Breusch-Godfrey Serial Correlation. Untuk menguji asumsi homoskedastisitas digunakan uji Breusch-Pagan-Godfrey. Sedangkan uji asumsi normalitas menggunakan uji Jarque-Bera.

\section{HASIL DAN PEMBAHASAN}

Penambahan harian kasus positif COVID-19 sampai dengan saat ini mengalami peningkatan yang tidak menentu. Pada awal bulan April, penambahan kasus masih di bawah angka 200 setiap harinya. Sementara itu, untuk pertama kalinya tanggal 9 Juli 2020 penambahan kasus positif menyentuh angka lebih dari 2500 orang. Meskipun beberapa kali sudah mulai mengalami penurunan, munculnya klaster-klaster penyebaran baru menimbulkan adanya gelombang penambahan kasus COVID-19 baru.

Berdasarkan analisis data penambahan harian kasus positif COVID-19 dengan smoothing data menggunakan moving average mingguan dan dua mingguan, apabila dilihat dari puncak penambahan kasus positif, saat ini penyebaran COVID-19 sudah memasuki gelombang penyebaran kelima. Hal ini bisa dilihat pada Gambar 1 melalui puncak-puncak gelombang yang terjadi. Puncak puncak gelombang ini sangat penting diketahui terutama di bidang kesehatan karena akan berhubungan dengan beban pekerjaan mereka yang akan lebih berat pada momen momen tersebut.
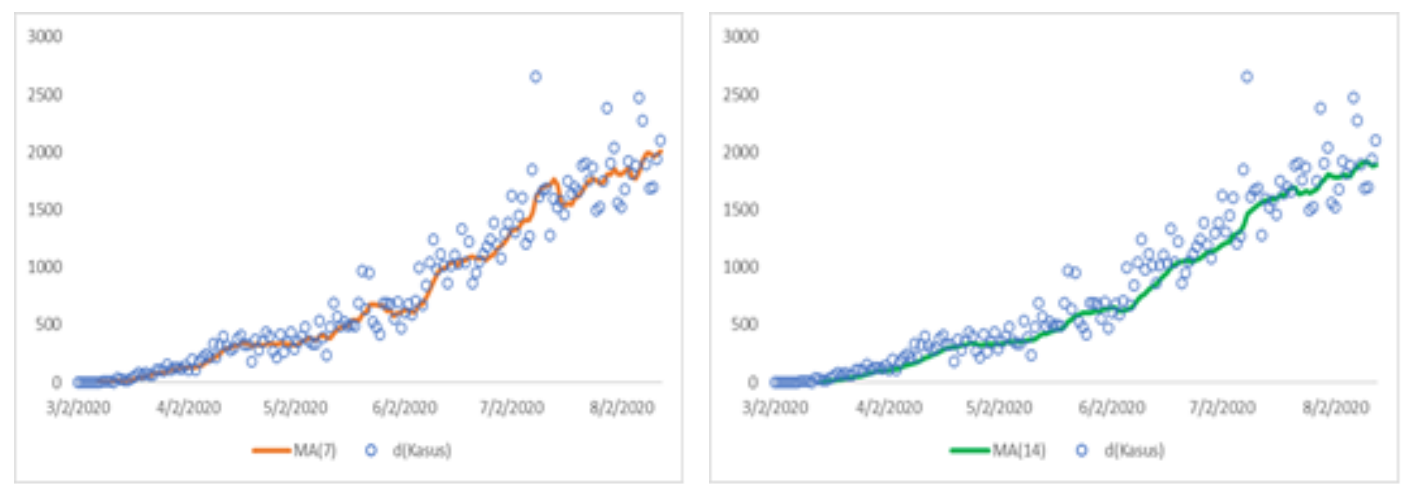

Gambar 1. Box Plot dan Garis Hasil Moving Average Smoothing Data Penambahan Kasus Positif COVID-19 di Indonesia

Gelombang penyebaran pertama terjadi sejak awal munculnya kasus positif COVID-19 pada tanggal 2 Maret 2020 sampai dengan awal bulan Mei 2020. Gelombang ini ditandai dengan puncak penambahan harian kasus positif pada minggu keempat bulan April 2020 yang kemudian mengalami penurunan pada awal bulan Mei 2020. Hasil perbandingan model pada penambahan kasus positif pada gelombang pertama ini dapat digambarkan sebagai berikut.

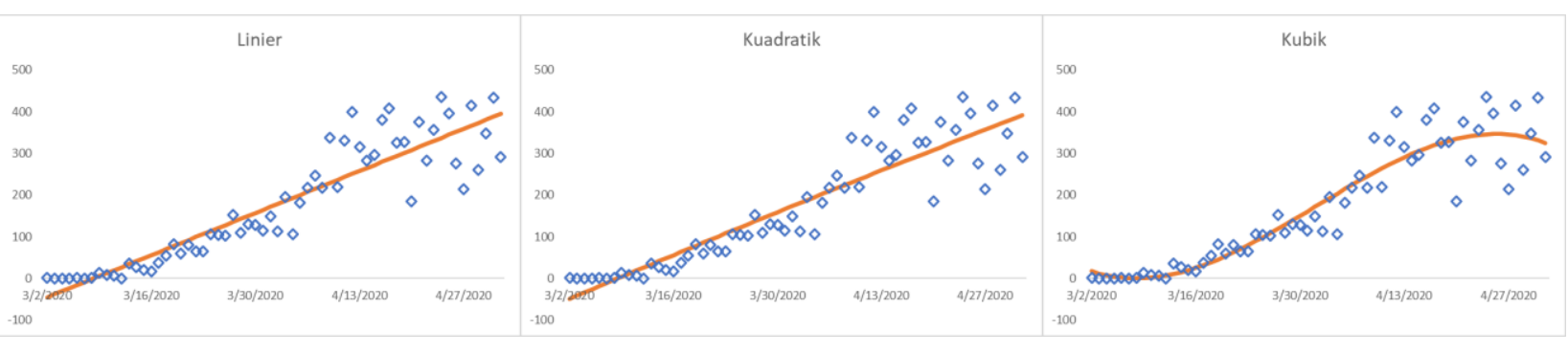




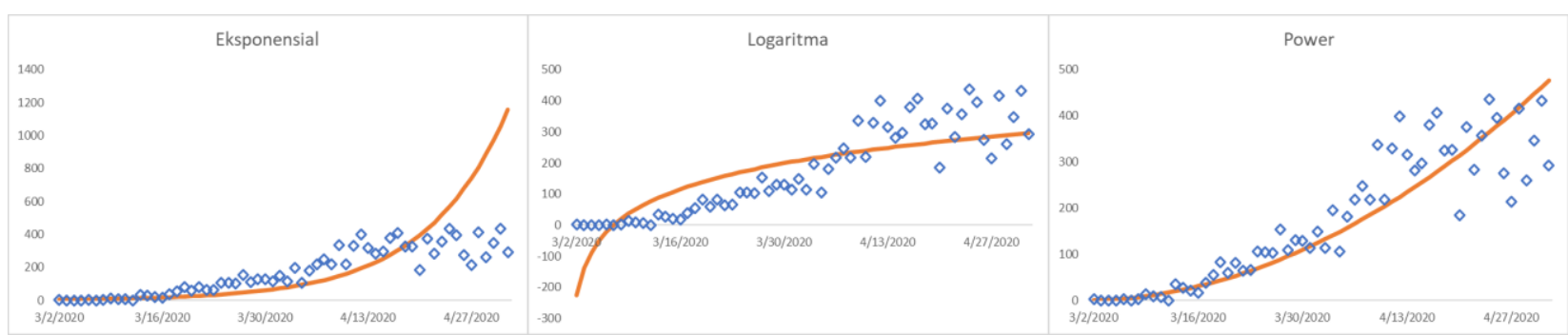

Gambar 2. Box Plot dan Garis Permodelan Data Penambahan COVID-19 pada Gelombang Pertaman di Indonesia

Berdasarkan Gambar 2, data penambahan kasus positif COVID-19 gelombang pertama ini lebih cenderung mengikuti model polinomial kubik. Dengan membandingkan antarmodel, polinomial kubik merupakan model yang paling baik dengan 87,34 persen bisa menjelaskan pergerakan data yang terjadi pada tingkat kepercayaan 95 persen. Sementara itu, nilai AIC, nonautokolineartias, homoskedastis dan kenormalan juga sudah sesuai. Dari hasil pemodelan yang diperoleh, diramalkan bahwa apabila penyebaran COVID-19 hanya terjadi satu gelombang, maka akhir dari penyebaran COVID-19 akan berakhir pada minggu ketiga bulan Mei 2020.

Gelombang penyebaran kedua terjadi pada awal bulan Mei 2020 sampai awal bulan Juni 2020. Gelombang ini ditandai dengan puncak penambahan kasus positif pada akhir bulan Mei 2020 yang kemudian sedikit mengalami penurunan pada awal bulan Juni 2020. Hasil permodelan terhadap penambahan kasus positif sampai dengan akhir gelombang kedua ini dapat digambarkan sebagai berikut.

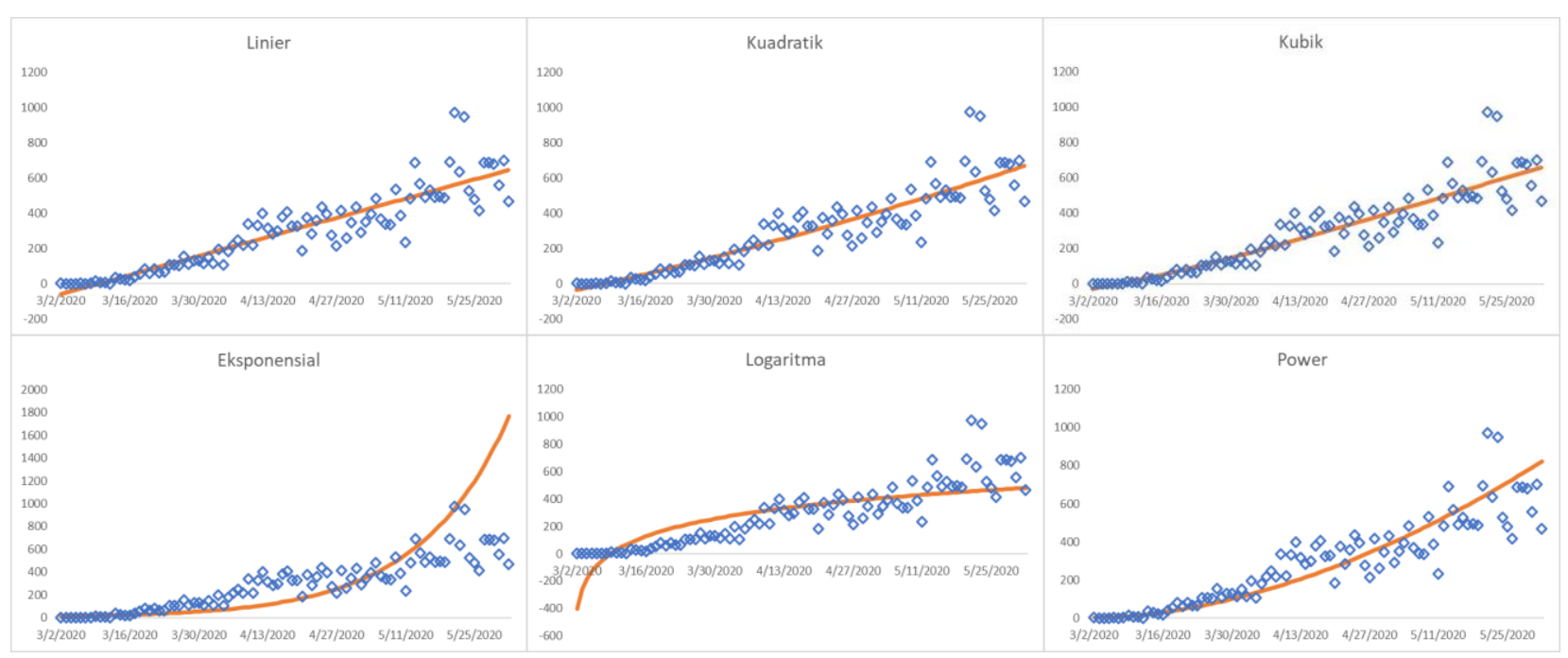

Gambar 3. Box Plot dan Garis Permodelan Data Penambahan COVID-19 sampai Gelombang Kedua di Indonesia

Berdasarkan Gambar 3, data penambahan kasus positif COVID-19 dari awal muncul sampai pada gelombang kedua ini lebih cenderung mengikuti model power. Analisa perbandingan model juga menghasilkan bahwa model power menjadi model terbaik dengan tingkat kepercayaan 95 persen bisa menjelaskan 89,64 persen pergerakan data. Sayangnya, model terbaik ini tidak dapat meramalkan kapan penyebaran COVID-19 ini akan berakhir karena tidak mempunyai ujung.

Gelombang penyebaran ketiga terjadi pada awal bulan Juni 2020 sampai akhir bulan Juni 2020. Gelombang ini ditandai dengan puncak penambahan kasus positif pada minggu ketiga bulan Juni 2020 yang kemudian bertahan tanpa mengalami peningkatan. Hasil permodelan terhadap penambahan kasus positif sampai dengan akhir gelombang ketiga ini dapat digambarkan sebagai berikut. 


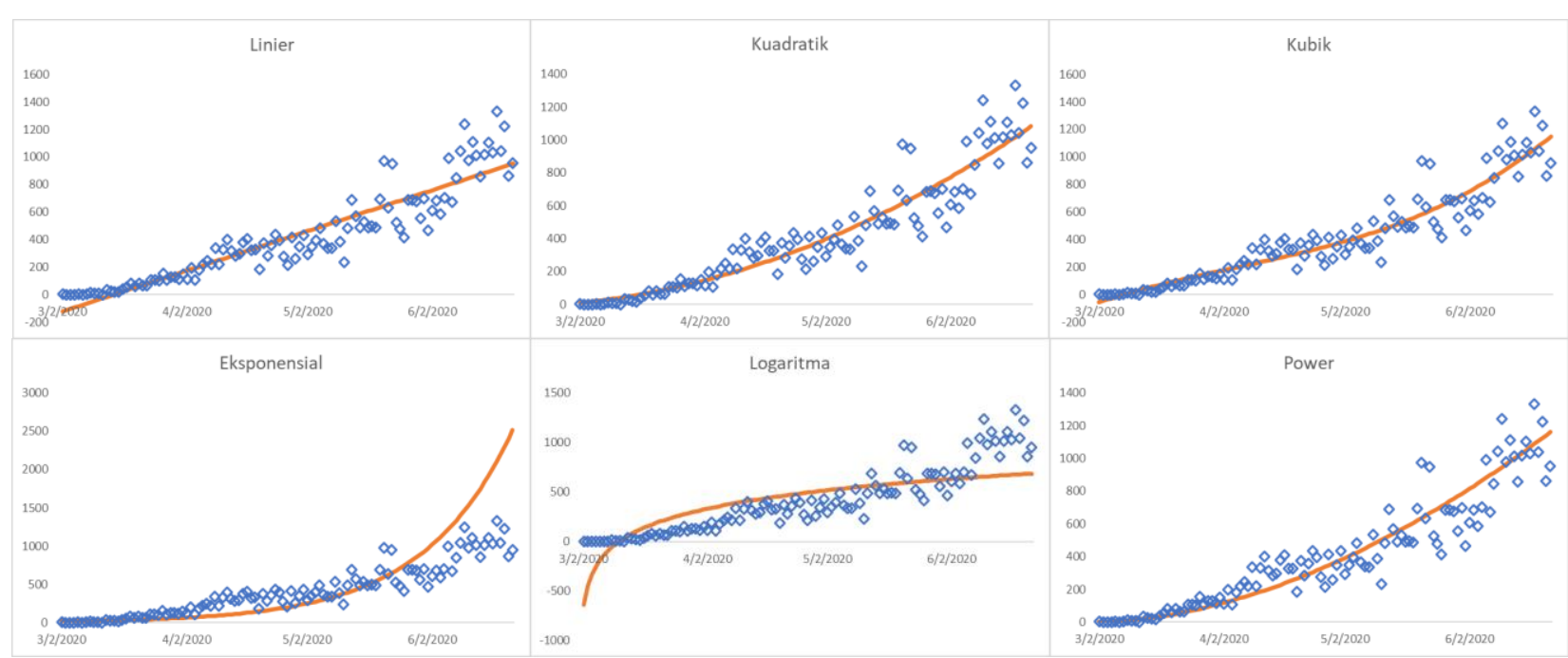

Gambar 4. Box Plot dan Garis Permodelan Data Penambahan COVID-19 sampai Gelombang Ketiga di Indonesia

Berdasarkan Gambar 4, data penambahan kasus positif COVID-19 dari awal muncul sampai pada gelombang ketiga ini lebih cenderung mengikuti model power. Perbandingan model juga menghasilkan model power adalah model terbaik yang mampu menjelaskan 91,26 persen pergerakan data pada tingkat kepercayaan 95 persen. Akan tetapi, permodelan terbaik yang diperoleh tidak dapat meramalkan kapan penyebaran COVID-19 ini akan berakhir.

Gelombang penyebaran keempat terjadi pada akhir bulan Juni 2020 sampai minggu ketiga bulan Juli 2020. Gelombang ini ditandai dengan puncak penambahan harian kasus positif pada minggu kedua bulan Juli 2020 yang kemudian mengalami penurunan pada minggu berikutnya. Hasil permodelan terhadap penambahan kasus positif sampai dengan akhir gelombang keempat ini dapat digambarkan sebagai berikut.

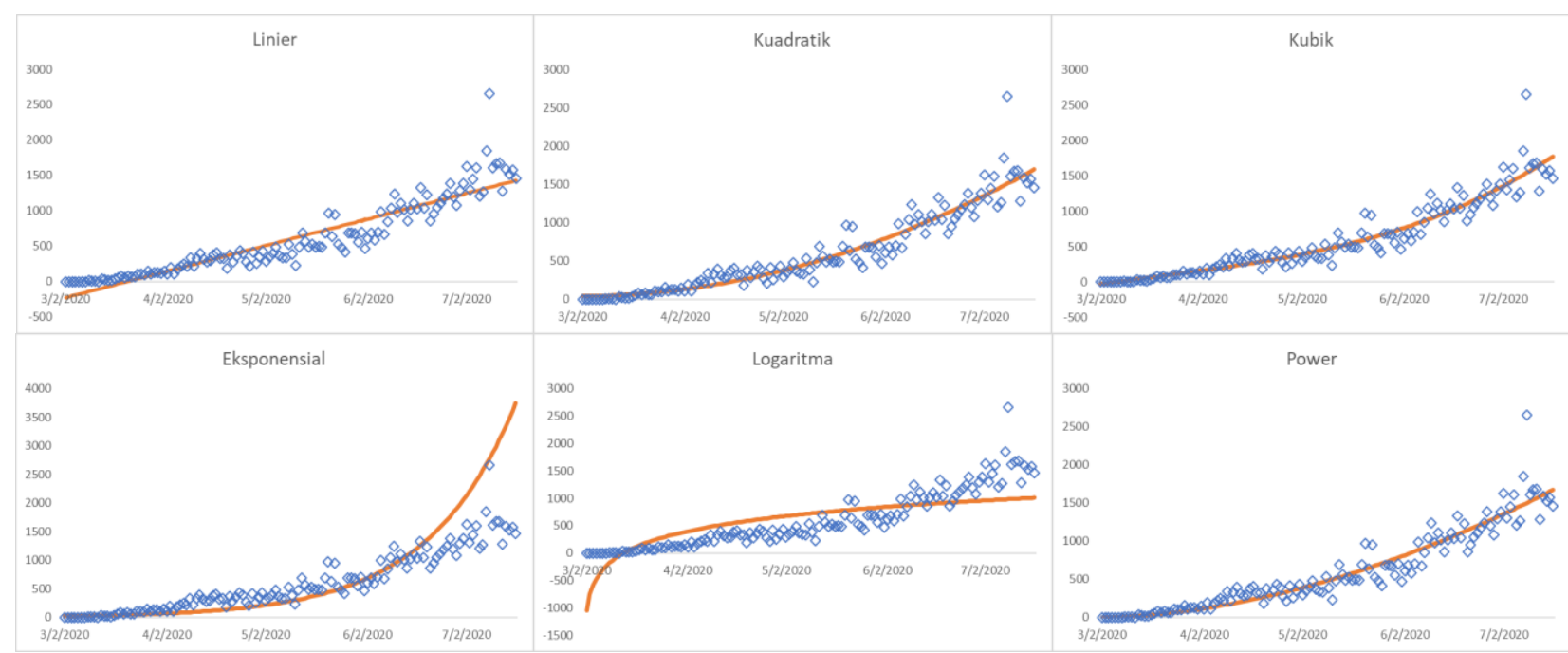

Gambar 5. Box Plot dan Garis Permodelan Data Penambahan COVID-19 sampai Gelombang Keempat di Indonesia

Berdasarkan Gambar 5, data penambahan kasus positif COVID-19 dari awal muncul sampai pada gelombang keempat ini lebih cenderung mengikuti model power. Analisa perbandingan model juga menghasilkan model power menjadi model terbaik yang mampu menjelaskan 92,74 persen pergerakan data. Dari model terbaik yang diperoleh tidak dapat meramalkan kapan penyebaran COVID-19 ini akan berakhir.

Gelombang penyebaran kelima terjadi pada minggu ketiga bulan Juli 2020 yang masih berlangsung sampai sekarang. Berdasarkan garis hasil moving average smooting data, gelombang kelima ini belum mencapai puncak penambahan kasus COVID-19. Artinya, masih memungkinkan terjadi puncak lonjakan penambahan kasus COVID-19 ke depannya pada gelombang kelima ini. 
Hasil permodelan terhadap penambahan kasus positif sampai dengan saat ini dapat digambarkan sebagai berikut.

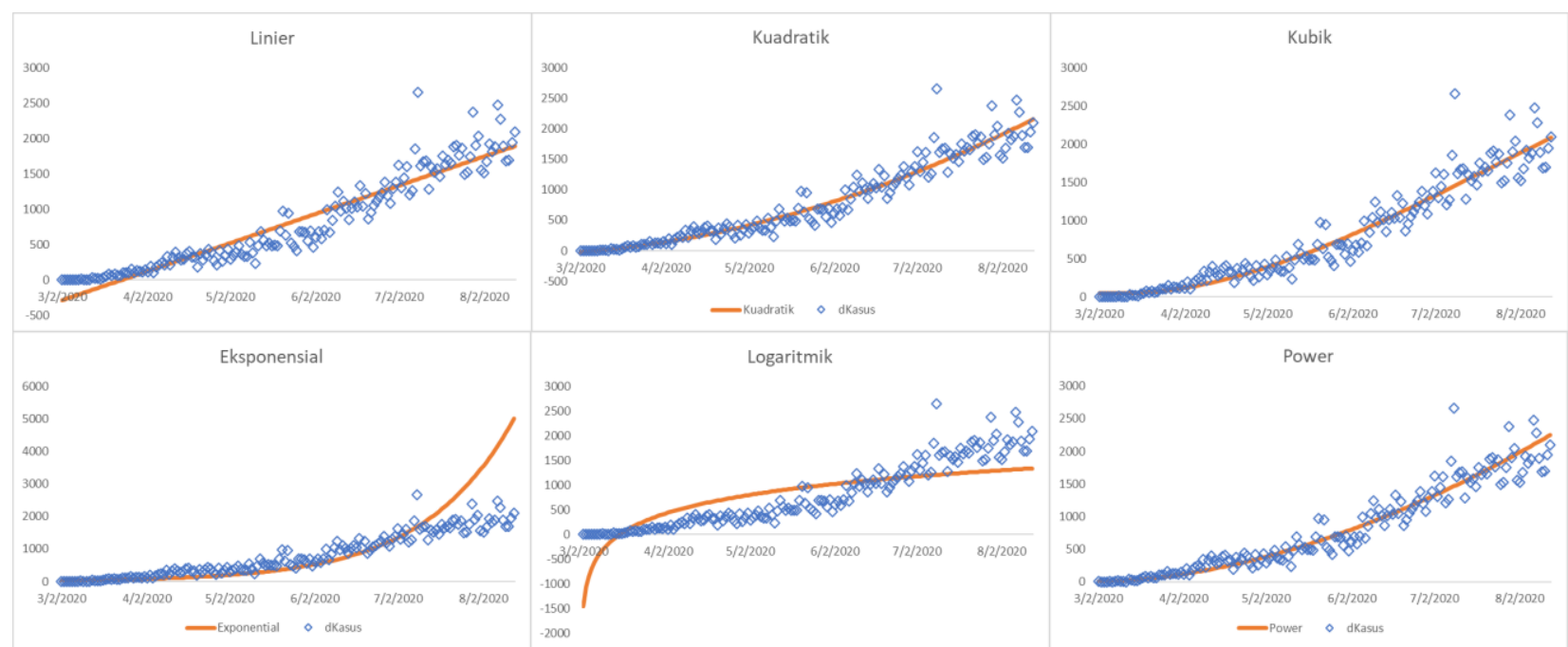

Gambar 6. Box Plot dan Garis Permodelan Data Penambahan COVID-19 sampai sekarang di Indonesia

Berdasarkan Gambar 6, data penambahan kasus positif COVID-19 dari awal muncul sampai pada gelombang kelima ini lebih cenderung mengikuti model polinomial kubik. Analisa perbandingan model juga menghasilkan model polinomial kubik menjadi model terbaik yang mampu menjelaskan 92,76 persen pergerakan data. Dari model terbaik yang diperoleh tersebut, ramalan pandemi di Indonesia akan berakhir pada 11 April 2021.

Sementara itu, data penambahan kasus positif COVID-19 dari awal muncul sampai pada gelombang kelima ini lebih cenderung mengikuti persamaan polinomial kubik. Dengan tingkat kepercayaan 95 persen, model tersebut mampu menjelaskan 92,76 persen pergerakan data yang ada. Hal ini sejalan dengan model terbaik pada gelombang kelima. Gambar 6 menunjukkan bahwa pergerakan data saat ini masih pada posisi sepertiga perjalanan.

Berdasarkan Gambar 6, puncak gelombang yang akan menjadi titik balik penurunan baru akan terjadi pada minggu keempat bulan November hingga minggu pertama bulan Desember 2020. Selama periode tersebut, diramalkan penambahan kasus positif menembus lebih dari 3200 kasus per harinya.

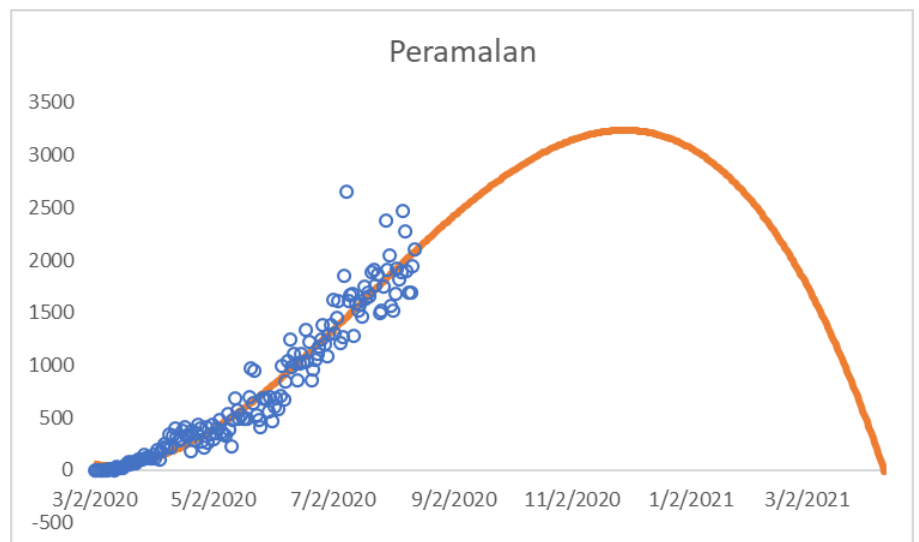

Gambar 6. Box Plot dan Garis Peramalan Penambahan COVID-19 dengan Persamaan Polinomial Kubik di Indonesia

Menggunakan model terbaik polinomial kubik, persamaan umum model seperti pada (4) sebagai berikut

$$
\mathrm{Y}=\mathrm{b} 0+\mathrm{b} 1 * \mathrm{t}+\mathrm{b} 2 * \mathrm{t} \wedge 2+\mathrm{b} 3 * \mathrm{t} \wedge 3
$$

Dengan memasukkan koefisien hasil analisis, maka didapatkan

$$
\mathrm{d}=380.0289+11.57741 * \mathrm{~T} 1+0.081861 * \mathrm{~T} 2-0.000344 * \mathrm{~T} 3
$$


Model terbaik yang diperoleh ini dapat meramalkan bahwa penyebaran COVID-19 di Indonesia baru akan berakhir pada minggu kedua bulan April 2021. Hal ini dapat terjadi apabila kondisi penyebaran COVID-19 di masyarakat masih mengikuti pola yang terjadi saat ini.

\section{KESIMPULAN}

Sejak awal muncul kasus pertama hingga saat ini, Covid19 berada pada posisi gelombang kelima dengan menganalisa detil puncak gelombang pada masing-masing periodenya. Hal ini sangat penting dilakukan karena akan memberikan warning pada bidang kesehatan sebagai akibat dari akan memberatnya beban mereka pada masing-masing puncak gelombang. Perbandingan model dilakukan untuk mendapatkan model terbaik dari setiap gelombangnya. Model terbaik gelombang 1 (terjadi dari awal hingga minggu keempat April) merupakan model polinomial kubik dengan prediksi berakhirnya pandemi di Indonesia pada minggu ketiga Mei 2020. Sementara itu, gelombang kedua, ketiga dan keempat mengikuti model power dengan tidak bisanya diramalkan akhir dari pandemi ini dengan periode masing-masing awal mei hingga awal Juni, awal Juni hingga akhir Juni, akhir Juni hingga minggu ketiga Juli. Sedangkan gelombang 5 (periode minggu ketiga Juli hingga saat ini) mengikuti model polinomial kubik dengan prediksi pandemi akan berakhir pada minggu kedua April 2021.

Sementara itu, data penambahan kasus positif dari awal hingga saat ini mengikuti model terbaik polinomial kubik yang mampu menjelaskan 92,76 persen dengan tingkat kepercayaan 95 persen. Hal ini sejalan dengan pola gelombang kelima. Puncak pandemi di Indonesia menggunakan model tersebut diramalkan terjadi pada minggu keempat November hingga minggu pertama Desember 2020. Sedangkan peramalan pandemi berakhir pada minggu kedua bulan April. Hasil penelitian ini akan terjadi apabila kondisi penyebaran COVID-19 di masyarakat masih mengikuti pola yang terjadi saat ini. Akan tetapi, jika ada kebijakan pemerintah yang bisa memutus rantai penyebaran lebih cepat dari yang terjadi saat ini, pandemi bisa saja lebih cepat berakhir. Sebaliknya, jika masyarakat mulai acuh dan mengabaikan protokol kesehatan, maka bisa dipastikan pandemi akan terjadi lebih lama dari yang sudah diramalkan, terlebih jika kluster kluster baru mulai bertambah. Keluarnya Indonesia dari pandemi ini membutuhkan kerjasama banyak pihak.

\section{DAFTAR PUSTAKA}

Ankarali, Hndan,dkk. A Statistical Modeling of the Course of COVID-19 (SARS-CoV-2) Outbreak: A Comparative Analysis.

SAGE Public Health Emergency Collection 1010539520928180. 2020, in

https://www.ncbi.nlm.nih.gov/pmc/articles/PMC7251623/ [15 September 2020]

Currie, Chistine, dkk. How Simulation Modelling Can Help Reduce The Impact Of COVID-19. Journal of Simulation VOL 14, No 2 83,97, 2020, in https://www.tandfonline.com/doi/full/10.1080/17477778.2020.1751570 [15 September 2020]

Garson, David. (2012). Curve Fitting \& Nonlinear Regression. G David Garson and Statistical Associates Publishing

Nuraini, N, dkk. Modeling Simulation of COVID-19 in Indonesia based on Early Endemic Data. COMMUN. BIOMATH. SCI. VOL. 3, NO. 1, 2020, PP. 1-8 in http://journals.itb.ac.id/index.php/cbms/article/view/13395/4641 . [15 September 2020] 